\title{
DIFFERENTIAL DIAGNOSTIC CHALLENGES DURING THE COVID-19 PANDEMIC FOR PEDIATRICIANS IN AN EASTERN EUROPEAN COUNTRY
}

\author{
Szofia Hajósi-Kalcakosz ${ }^{1}$, Borbála Zsigmond ${ }^{1}$, Andrea Párniczky², Réka Bodnár². \\ ${ }^{1}$ Department of Infectious Diseases, Heim Pál Children's Hospital, Budapest, Hungary, \\ ${ }^{2}$ Cystic Fibrosis Outpatient Care Unit, Heim Pál Children's Hospital, Budapest, Hungary.
}

\section{KEYWORDS}

Covid-19, SARS-CoV-2, cystic fibrosis, newborn screening

\section{ARTICLE HISTORY}

Received 5 February 2021

Accepted 4 March 2021

\section{Clinical Problem:}

A two-year-old girl was admitted to a local hospital in Hungary in March 2020 with fever, difficulty in breathing and one week history of coughing. She had chronic cough, frequent respiratory illnesses, and inability to gain weight since infancy. Due to her present respiratory symptoms, a SARS-CoV-2 PCR test was carried out and the result was positive, therefore she was transferred to our hospital. On presentation to us, she had tachypnea (respiratory rate: 58/min), wheezing, lung crackles, hepatomegaly and clubbing of the fingers. Her oxygen saturation was $95 \%$ on $3 \mathrm{~L} / \mathrm{min}$ oxygen flow with the nebulizing mask. She was malnourished according to the Hungarian longitudinal growth chart: body weight: $9.8 \mathrm{~kg}$ ( $3^{\text {rd }}$ percentile), height: $88 \mathrm{~cm}$ ( $50^{\text {th }}$ percentile), body mass index $12.65 \mathrm{~kg} / \mathrm{m}^{2}$ ( $<3^{\text {rd }}$ percentile, $\mathrm{Z}$ score $=-1.99)$. Laboratory evaluation showed high white blood cell count $(27,820$ cells/cumm $)$ with neutrophilia $(23,600$ cells/cumm). Shortly after admission her work of breathing significantly increased, therefore high flow nasal cannula (HFNC) oxygen therapy was implemented. Despite the frequent use of bronchodilators and steroids, wheezing did not improve. On the $10^{\text {th }}$ day of her illness, nasopharyngeal swab for SARS-CoV-2 by PCR was positive. At that time the CRP was in the normal range (CRP $1.65 \mathrm{mg} / \mathrm{L}$ ), white blood cell count was slightly elevated $(17,960$ cells/cumm). Other inflammatory markers were not measured. The PCR result was a surprise as the case did not fulfill the environmental criteria of Covid-19 infection. First of all, the girl came from the rural part of Eastern Hungary where the number of confirmed Covid-19 cases were extremely low, and secondly, no one in the family was confirmed to be positive either. Hence, nasopharyngeal swab for SARS-CoV-2 by PCR was repeated and SARS-CoV-2 IgM was taken. All the tests were found to be negative, therefore we excluded the diagnosis of Covid-19. On day 10 after admission, she was transferred to the Pediatric Intensive Care unit for invasive ventilation due to further respiratory distress on HFNC. She required 10 days of mechanical

Address for Correspondance: Szofia HajósiKalcakosz, Heim Pál Children's Hospital, 1089, Ülloi Street 86., Budapest, Hungary.

Email: szofia.kalcakosz@gmail.com

(C2021 Pediatric Oncall ventilation. Due to the worsening clinical picture, high resolution computed tomography was performed, which revealed bronchial wall thickening, mucus plugging and bronchiectasis. (Figure 1).

Figure 1. Chest CT: Peribronchial thickening, mucus plugging and severe bronchiectasis in the lungs

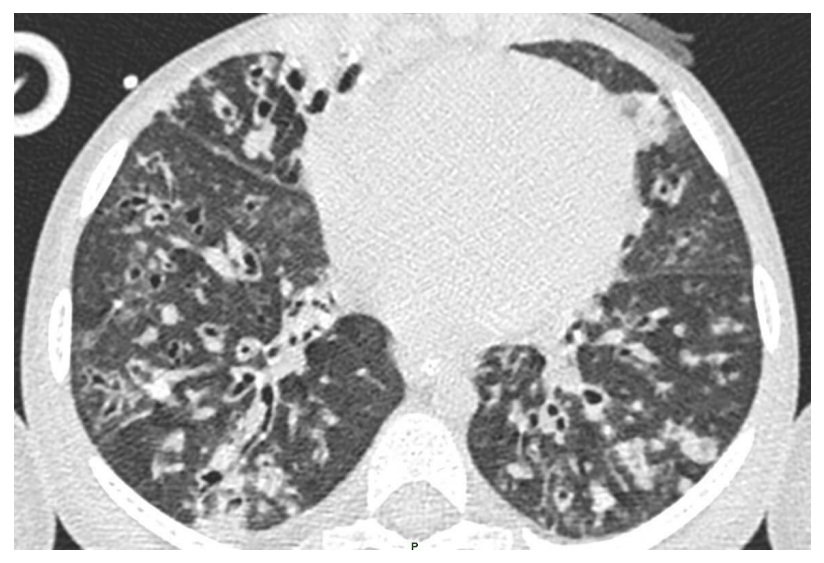

Is this COVID-19 infection in the girl?

\section{Discussion:}

The gold standard for detecting Covid-19 disease in clinical practice is RT-PCR. In March 2020, when this child presented to us, no false positive SARS-CoV-2 PCR result was reported in literature. According to our recent knowledge, above 34 replication cycles no positive viral culture is obtained. ${ }^{1}$ Our explanation for the initial positive test could have come from the fact that our laboratory repeated the PCR replication above 34 cycles and nonspecific signals were misinterpreted positive. The preliminary estimates of false-positive PCR tests in the United Kingdom is $0.8-4.0 \% .^{2}$ Contamination during sampling, contamination by PCR amplicons, contamination of reagents, cross-reactions with other viruses can also be responsible for false-positive results. ${ }^{2}$ In our patient, past medical history was suggestive of a possibility of an underlying chronic lung condition. Sweat chloride test was $112 \mathrm{mmol} / \mathrm{l}$ (normal: <40 mmol/l) which confirmed the diagnosis of cystic fibrosis (CF), and a genetic test revealed a F508 del and G542X mutation. In Europe there are many different CF new born screening (NBS) protocols. All current protocols rely on 
immunoreactive trypsinogen (IRT) at birth, intermediate tiers consists of cystic fibrosis transmembrane conductance regulator (CFTR) mutation analysis or an IRT resampling, and as a last step a sweat chloride test is made to distinguish between NBS false and true positive cases. ${ }^{3}$ In Hungary national NBS program is not available yet, however, the protocol is elaborated for years. ${ }^{4}$ Our experience suggests that the lack of national NBS program of CF leads to delayed diagnosis. Early diagnosis and CF specific therapy from the early stage may protect lungs from serious damages and disease progression. In the meantime, clinicians in Hungary should always consider CF as part of their differential diagnosis in cases with recurrent respiratory infections and failure to thrive.

\section{Acknowledgement}

The authors would like to express thanks to Katalin Márai MD, for her clinical advices in the diagnosis and intensive care management of this case.

\section{Compliance with ethical standards}

Funding: None

Conflict of Interest: None

\section{References:}

1. La Scola B, Le Bideau M, Andreani J, Hoang VT, Grimaldier C, Colson P et al. Viral RNA load as determined by cell culture as a management tool for discharge of SARS-CoV-2 patients from infectious diseases wards. Eur J Clin Micorbiol Infect Dis 2020; 39:1059-1061.

2. Mayers C, Baker K. Impact of false-positives and falsenegatives in the UK's Covid-19 RT-PCR testing programme. Paper prepared for the Government Office of Science. 2020. Available from: https://assets.publishing.service.gov.uk/ government/uploads/system/uploads/attachment_data/ file/895843/S0519_Impact_of_false_positives_and_ negatives.pdf. Accessed on 3rd June 2020

3. Castellani C, Southern K, Brownlee K, Dankert Roelse J, Duff $A$, Farrell $M$ et al. European best practice guidelines for cystic fibrosis neonatal screening. J Cyst Fibros. 2009;8:153-173.

4. Kalmár $T$, Nagy $D$, Újhely $R$, Bede $O$, Maróti $Z$, Vécseiné Karg $\mathrm{E}$ et al. A cystás fibrosis újszülöttkori szürése és az azt követő teendők. Mucoviscidosis Hungarica 2018;4:229245. 